Journal of Immunogenetics (1975) 2, 415-424.

\title{
SPECIFIC INHIBITION OF LYMPHOID COMPLEMENT RECEPTORS BY ANTI-H-2 SERA: EVIDENCE FOR A NEW H-2 LINKED POLYMORPHISM
}

\author{
A. Arnaiz-Villena, P. Halloran, C. S. David* and \\ H. FESTENSTEIN \\ Department of Tissue Immunology, The London Hospital Medical College, Turner Street, \\ London, England and ${ }^{*}$ Department of Human Genetics, University of Michigan, Ann Arbor, \\ Michigan, U.S.A.
}

(Received 1 July 1975)

\begin{abstract}
SUMMARY
Certain anti-H-2 sera contain an antibody-like activity which specifically inhibits EAC rosette formation by lymphoid (and not myeloid) cells of certain mouse strains. Studies in congenic recombinant mouse strains strongly indicate that at least part of the control of susceptibility to inhibition by these antisera is mediated by $\mathrm{H}-2$ linked genes, mapping in the $\mathrm{I}-\mathrm{C}$ subregion or the $\mathrm{S}$ region. The strain distribution of the trait CRIS indicates that certain $\mathrm{H}-2$ identical mice behave differently from one another, pointing toward a component of non- $\mathrm{H}-2$ modulation of the $\mathrm{H}-2$ linked gene (or to a previously unsuspected $\mathrm{H}-2$ difference). Positive sera were usually raised across differences in the $D$ end of the $\mathbf{H}-2$ complex. The complex implications of this system must be considered in the light of known $\mathrm{S}$ region involvement in complement metabolism.
\end{abstract}

\section{INTRODUCTION}

The complement receptor (CR) like the Fc receptor, is a well-documented component of the cell surface of macrophages and B lymphocytes (Lay \& Nussenzweig, 1968; Bianco et al., 1970). Moreover, like Fc receptors, evidence exists for its presence on subpopulations of $T$ lymphocytes and 'null' lymphocytes (Arnaiz-Villena et al., 1974; Arnaiz-Villena \& Hay, 1975).

However, while $\mathrm{Fc}$ receptors are completely inhibited by preincubation of the cells with alloantisera (Parish \& Hayward, 1974, Dickler \& Sachs, 1974; Schirrmacher et al., 1975; Halloran et al., 1975) the CR has been reported to resist such inhibition both in rat and in mouse (Parish \& Hayward, 1974; Dickler \& Sachs, 1974).

We have been studying a mouse CR dependent system in which $\mathrm{CR}$ binding is detected by rosette formation between mouse cells and antibody- and complement-coated sheep

Correspondence: Dr A. Arnaiz-Villena, Department of Immunology, Clinica Puerta de Hierro, Universidad Autonoma, Madrid 35, Spain. 
erythrocytes (EAC). Preincubation of the mouse cells with certain mouse $\mathrm{H}-2$ alloantisera was found to specifically and consistently inhibit most of these EAC rosettes in some (but not all) mouse strains. This suggested that mouse CR inhibition susceptibility (CRIS) by H-2 alloantisera might be controlled by one or more previously unsuspected genetic loci.

We have attempted to answer certain questions about this system: (i) is the inhibitory activity in $\mathrm{H}-2$ alloantisera antibody? (ii) what population of EAC-rosette forming cells is inhibited? (iii) is the genetic control of CRIS H-2 linked, and if so, can it be mapped in congenic resistant recombinant mouse strains? (iv) what is the strain distribution of the characteristic CRIS ? (v) is CRIS genetically controlled by one locus or multiple loci? (vi) what are the genetic requirements for the production of the inhibitory activity in an $\mathbf{H}-2$ alloantiserum?

Preliminary results of some of these studies have been presented elsewhere (ArnaizVillena et al., 1975). The results presented here suggest that CRIS is under complex genetic control in part $\mathrm{H}-2$ linked.

\section{MATERIALS AND METHODS}

Animals

Two to three month old male and female mice were used. Strains AKR, CBA/H, C3H, B10.BR, DBA/2, BALB/c, C57B1/6, C57B1/10 ('B10'), B10.A and A.JAX were bred in the London Hospital Medical College from breeding pairs obtained from Laboratory Animal Centre, Carshalton, England. Strains B10.HTT, B10.A(2R), B10.A(5R), B10.A(4R), B10.A(R233), A.TH, A.TL and A.SW were bred in this laboratory from breeding pairs obtained from Dr P. Démant, Institute of Experimental Biology and Genetics, Praha, Czechoslovakia, and from Dr D. Shreffler, Department of Human Genetics, University of Michigan Medical School, Ann Arbor, Michigan, U.S.A. B10.M were obtained from Searle Research Laboratories, High Wycombe, England.

\section{Antisera}

The different allogeneic and xenogeneic sera were obtained as described by Halloran et al. (1975) and Arnaiz-Villena \& Hay, (1975). IgG and $F\left(a b^{\prime}\right)_{2}$ fragments were obtained as detailed by Halloran et al. (1974).

Table 1 shows details about $\mathrm{H}-2$ antisera. Sera 3, 4, 6, and 7 were obtained from the Transplantation Immunology Branch, N.I.A.I.D., N.I.H., Bethesda, Md., U.S.A., (Snell, 1968).

\section{Preparation of $E A C$}

Sheep red blood cells (SRBC, E), rabbit anti-SRBC antibody (A) at subagglutinating doses or alternatively pure mouse IgM anti-SRBC (from Dr F. C. Hay) and fresh mouse complement were used as described by Arnaiz-Villena et al. (1974). Complement was obtained by axillary bleeding of $(\mathrm{B} 10 . \mathrm{BR} \times \mathrm{B} 10) \mathrm{F}_{1}{ }^{*}$ hybrids, blood being kept at $4^{\circ} \mathrm{C}$ to separate the serum, which was always used the same day. A final suspension of EAC was made up in veronal buffered physiological saline, containing $\mathrm{Ca}^{2+}$ and $\mathrm{Mg}^{2+}$ (VBS).

* The source of complement appears to have no bearing on the results. (BALB/c $\times$ C57B1/6) $\mathrm{F}_{1}$ and $B A L B / c$ have also been used, with identical results. 
TABLE 1. Specificity of H-2 antisera

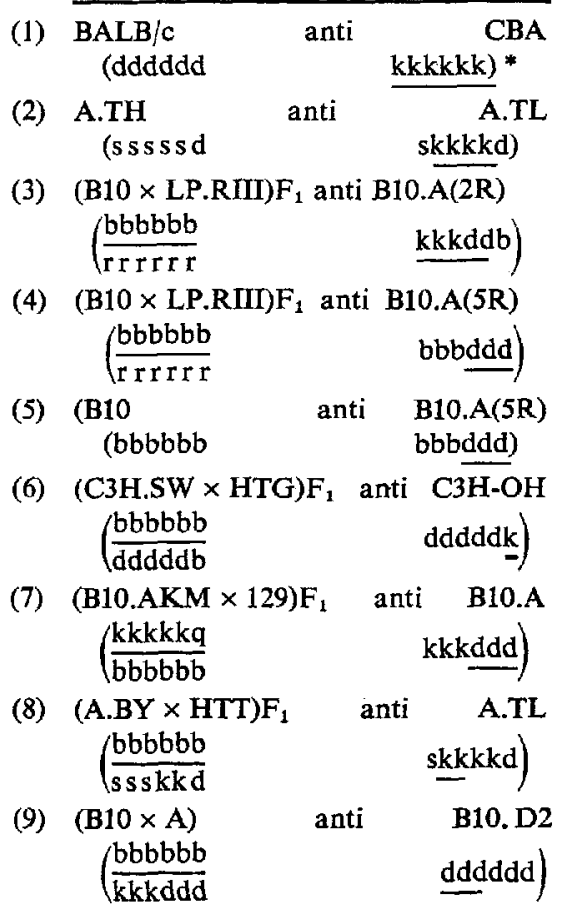

\footnotetext{
* The small case letters in brackets represent the alleles at the various regions and subregions of the $\mathrm{H}-2$ complex, designated by their genetic origin (e.g. $b=H-2^{b}$ ) and appearing in the following order: $\mathrm{K}, \mathrm{I}-\mathrm{A}, \mathrm{I}-\mathrm{B}, \mathrm{I}-\mathrm{C}$, S, D. (Klein et al., 1974).
}

\section{Cell suspensions}

Cell suspensions from spleen were obtained by teasing in VBS. Aggregates were allowed to sediment and the supernatant was collected. The cells were washed twice with VBS at $4^{\circ} \mathrm{C}$ and finally resuspended in VBS up to the adequate concentration.

\section{Inhibition and C'rosette assay}

The mouse cells, $5 \times 10^{6}$, were incubated with $100 \mu \mathrm{l}$ of the appropriate dilution of antiserum in VBS for 20 min at room temperature. After two washes with cold VBS, cells were mixed together with EAC in VBS (50 EAC: 1 lymphocyte) in flat bottomed plastic tubes with caps $(45 \times 10 \mathrm{~mm})$ and then left standing at room temperature for $1 \mathrm{hr}$. E and EA negative controls were run in parallel.

Specific percentage inhibition was calculated by comparison with the amount of inhibition of control cells by normal A.SW serum in each experiment, usually negligible. Total leucocytes and total rosettes were counted in the same field after adding one drop $0.01 \%$ acridine orange into each tube and examining the cells under fluorescence microscopy, using simultaneous ultraviolet and visible transmitted light. At least 400 cells were counted. 


\section{RESULTS}

As presented in our earlier communication, (Arnaiz-Villena et al., 1975) the inhibitory activity was initially detected in two alloantisera involving $\mathrm{H}-2$ or partial $\mathrm{H}-2$ differences: A.TH anti-A.TL, and BALB/c anti-CBA/H. Preincubation of AKR spleen or lymph node cells with either of these antisera was found to inhibit their ability to form EAC rosettes. - BALB/c cells were unaffected by these antisera. The inhibition was invariably found to be only partial ( $70 \%$ with spleen cells, $80-90 \%$ with lymph node cells), and little or no inhibition occurred with bone marrow cells. Since the use of EDTA allows one to study either 'myeloid' (EDTA sensitive) or 'lymphoid' (EDTA resistant) rosette forming cells (Lay \& Nussenzweig, 1968; Arnaiz-Villena et al., 1974) we were able to show that only the 'lymphoid' population of EAC rosette forming cells in spleen and lymph node were inhibited by these alloantisera. Male and female mice were equally susceptible to inhibition.

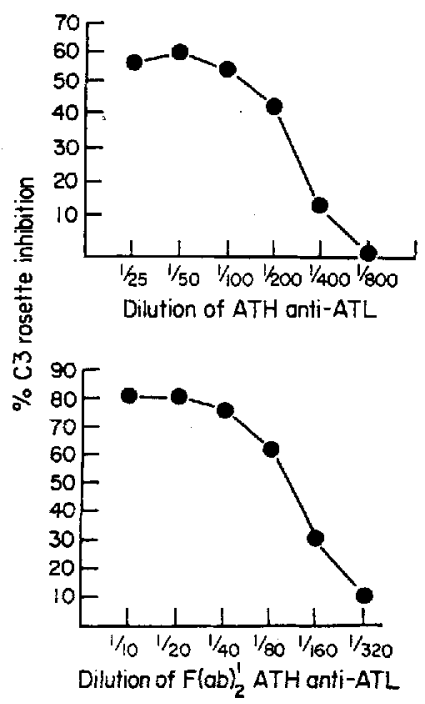

FIG. 1. Inhibition of complement receptors by A.TH anti-A.TL serum in AKR spleen cells.

In the present studies, we sought to determine whether the inhibitory activity was antibody. The observation that normal mouse sera showed no inhibitiory activity and that the activity appeared after immunization was suggestive. Also, Fig. 1 shows results with IgG and $F\left(a b^{\prime}\right)_{2}$ fractions of the A.TH anti-A.TL serum. The strong inhibition of EAC rosettes observed with the $\mathrm{F}\left(\mathrm{ab}^{\prime}\right)_{2}$ preparation is most compatible with an antibody acting by binding to the cell surface by the antibody combining site, independent of the Fc portion of the molecule. Further evidence that the activity was antibody was the demonstration that the activity could be specifically absorbed, as described later.

What was the linkage of the genetic control of CRIS? Some preliminary studies done in highly inbred $\mathrm{F}_{2}$ recombinant mice (provided by $\mathrm{B}$. Taylor) have strongly suggested that at least some of the genetic control segregates together with the H-2 type of the mouse in the $\mathrm{DBA} / 2 \times \mathrm{C} 57 \mathrm{~B} 1 / 6$ combination tested; further studies to confirm these findings are in 
progress. In addition, some studies in congenic mouse strains have been done, as shown in table 2. Since B10 was negative (i.e. not inhibited) and B10.A was positive (i.e. inhibited), a locus in the IXth linkage group was indicated. Since B10.A(5R) was positive, this locus must be to the right of I-B, and since B10.A(2R) was positive it must be to the left of H-2D. Thus an $\mathrm{H}-2$ locus between the I-B subregion and the $\mathrm{D}$ region (either $\mathrm{I}-\mathrm{C}$ or $\mathrm{S}$ ) must make some contribution to the genetic control of CRIS.

TABLE 2. $\mathrm{C}^{\prime}$ receptor blocking by A.TH $\propto$ A.TL serum in B10 congeneic series

\begin{tabular}{|c|c|c|c|c|c|c|c|c|}
\hline \multirow[b]{2}{*}{ Strain } & \multicolumn{6}{|c|}{$\mathrm{H}-2$ region } & \multirow{2}{*}{$\begin{array}{c}\text { Normal CRC } \\
\text { numbers }\end{array}$} & \multirow{2}{*}{$\begin{array}{l}\% \mathrm{C}^{\prime} \text { rosette } \\
\text { inhibition } \dagger\end{array}$} \\
\hline & $\mathbf{K}$ & $\mathbf{I}-\mathbf{A}$ & I-B & $\mathrm{I}-\mathrm{C}$ & $\mathbf{S}$ & $\mathrm{D}$ & & \\
\hline B10 & b & $b$ & $\mathrm{~b}$ & b & b & $\mathrm{b}$ & $31 \pm 5$ & 0 \\
\hline B10.A & $\mathbf{k}$ & k & k & d & $d$ & $\mathrm{~d}$ & $30 \pm 6$ & $72 \pm 5$ \\
\hline $\mathrm{B} 10 . \mathrm{A}(2 \mathrm{R})$ & $\mathbf{k}$ & k & $\mathrm{k}$ & d & d / & $\mathrm{b}$ & $23 \pm 4$ & $70 \pm 3$ \\
\hline B10.A(4R) & $\mathbf{k}$ & k / & $\mathrm{b}$ & $b$ & $\mathrm{~b}$ & b & $22 \pm 5$ & 0 \\
\hline $\mathrm{B} 10 . \mathrm{A}(5 \mathrm{R})$ & $b$ & b & b / & d & d & d & $33 \pm 6$ & $71 \pm 5$ \\
\hline B10.A(R233) $\ddagger$ & $\mathbf{k}$ & k & $\mathrm{k}$ & $\mathrm{d}$ & d $/$ & $\mathrm{b}$ & $26 \pm 2$ & $74 \pm 5$ \\
\hline
\end{tabular}

* Values are mean \pm of 5 separate experiments. $C R C=$ complement receptor cells.

† See footnote to Table 3.

¥ So far H-2 unđistinguishable from B10.A(2R) P. Démant (personal communication)

The strain distribution of the characteristic CRIS as defined by the two antisera (A.TH $\alpha$ A.TL and BALB/c $\alpha$ CBA/H) is shown in Table 3. Since AKR and B10.A had previously been shown to be positive for CRIS, it was not surprising that the positive strains should have $\mathrm{I}-\mathrm{C}^{\mathrm{k}} / \mathrm{S}^{\mathrm{k}}$ or $\mathrm{I}-\mathrm{C}^{\mathrm{d}} / \mathrm{S}^{\mathrm{d}}$ in their $\mathrm{H}-2$ haplotypes. Yet some of the negative strains were apparently $\mathrm{H}-2$ identical with positive strains: BALB/c $\left(\mathrm{H}-2^{\mathrm{d}}\right)$ was negative but $\mathrm{DBA} / 2$ $\left(\mathrm{H}-2^{\mathrm{d}}\right)$ was positive; $\mathrm{B} 10 . \mathrm{BR}, \mathrm{CBA} / \mathrm{H}$, and $\mathrm{C} 3 \mathrm{H}$ (all $\mathrm{H}-2^{\mathrm{k}}$ ) were negative but $\mathrm{AKR}\left(\mathrm{H}-2^{\mathrm{k}}\right)$ was positive. Also the antiserum $\mathrm{BALB} / \mathrm{c}$ anti $\mathrm{CBA} / \mathrm{H}$ was negative with $\mathrm{CBA} / \mathrm{H}$, which was the immunizing strain, and positive with AKR. These data implied that the $\mathrm{H}-2$ linked genetic control demonstrated in the congenic mice could not alone explain the strain distribution of the characteristic CRIS. Another observation shown in Table 3 is that CRIS is expressed in a dominant fashion in the (BALB/c $\times A K R) F_{1}$ mice.

Further clarification of the question of genetic control was sought through absorption experiments. Table 4 shows that while $\mathrm{CBA} / \mathrm{H}$ cells are not themselves inhibited by the antisera BALB/c anti-CBA/H or A.TH anti-A.TL, they will absorb much of the inhibitory activity (as tested on AKR cells) out of these antisera. BALB/c cells were not inhibited by the antisera, nor would they absorb out the inhibitory activity. AKR cells were inhibited by the antisera and would also absorb out the activity. Thus at least three phenotypes are possible for the characteristic CRIS: inhibition +, absorption + (e.g. AKR); inhibition -, absorption + (e.g. CBA/H); inhibition -, absorption - (e.g. BALB/c). This situation strongly suggests the operation of a non $\mathrm{H}-2$ genetic locus in the control of CRIS, in addition to the H-2 linked locus previously suggested. Genetic studies to confirm this conclusion are in progress.

In order to obtain information about the genetic requirements for the production of the inhibitory antisera, we undertook to assess a variety of other antisera, directed against 
TABLE 3. Strain distribution of $C^{\prime}$ receptor inhibition by A.TH anti-A.TL and BALB/c anti-CBA antisera *

\begin{tabular}{|c|c|c|c|c|c|c|c|c|c|}
\hline Strains & $(\mathrm{K}$ & $\underset{\mathrm{I}-\mathrm{A}}{\mathrm{H}}$ & $\begin{array}{l}-2 \mathrm{CC} \\
\mathrm{I}-\mathrm{B}\end{array}$ & I-C & ex & D) & $\begin{array}{c}\text { Normal CRC } \\
\text { number } \|\end{array}$ & $\begin{array}{c}\% \text { inhibition } \\
\text { A.TH } \propto \text { A.TL } \dagger\end{array}$ & $\begin{array}{l}\% \text { inhibition } \\
\text { BALB } / \mathrm{c} \propto \text { CBA }\end{array}$ \\
\hline \multicolumn{10}{|l|}{ Positive $\ddagger$} \\
\hline AKR & k & $\mathrm{k}$ & k & $\mathbf{k}$ & $\mathbf{k}$ & k & $31 \pm 5$ & $70 \pm 3$ & $72 \pm 5$ \\
\hline $\mathrm{DBA} / 2$ & $d$ & $d$ & $\mathrm{~d}$ & $\mathrm{~d}$ & $\mathrm{~d}$ & d & $25 \pm 2$ & $65 \pm 2$ & $68 \pm 4$ \\
\hline A.JAX & k & k & $\mathbf{k}$ & d & $\mathrm{d}$ & d & $29 \pm 6$ & $63 \pm 2$ & $67 \pm 1$ \\
\hline B10.A & $\mathrm{k}$ & $\mathrm{k}$ & k & $\mathrm{d}$ & d & $\mathrm{d}$ & $30 \pm 6$ & $72 \pm 5$ & $72 \pm 7$ \\
\hline B10.HTT & $\mathbf{s}$ & s & $\mathbf{s}$ & $\mathbf{k}$ & $\mathrm{k}$ & d & $31 \pm 1$ & $75 \pm 4$ & $70 \pm 1$ \\
\hline A.TL & $\mathbf{s}$ & $\mathbf{k}$ & $\mathbf{k}$ & $\mathbf{k}$ & $\mathbf{k}$ & $\mathrm{d}$ & $2 \overline{3}$ & 71 & 65 \\
\hline$(\mathrm{BALB} / \mathrm{c} \times \mathrm{AKR}) \mathrm{F}_{1}$ & $\frac{k}{d}$ & $\frac{\mathrm{k}}{\mathrm{d}}$ & $\frac{\mathrm{k}}{\mathrm{d}}$ & $\frac{k}{d}$ & $\frac{k}{d}$ & $\frac{\mathrm{k}}{\mathrm{d}}$ & $27 \pm 4$ & $68 \pm 1$ & $69 \pm 5$ \\
\hline \multicolumn{10}{|l|}{ Negative } \\
\hline $\mathrm{CBA} / \mathrm{H}$ & k & k & $\mathbf{k}$ & $\mathbf{k}$ & $\mathrm{k}$ & $\mathbf{k}$ & $32 \pm 3$ & 0 & 0 \\
\hline $\mathrm{C} 3 \mathrm{H}$ & $\mathbf{k}$ & $\mathbf{k}$ & $\mathbf{k}$ & $\mathrm{k}$ & $\mathrm{k}$ & $\mathbf{k}$ & $30 \pm 4$ & 0 & 0 \\
\hline B10.BR & $k$ & k & $\mathrm{k}$ & $\mathbf{k}$ & $\mathrm{k}$ & $\mathbf{k}$ & $28 \pm 4$ & 0 & 0 \\
\hline $\mathrm{BALB} / \mathrm{c}$ & d & $d$ & $\mathrm{~d}$ & $\mathrm{~d}$ & d & d & $28 \pm 4$ & 0 & 0 \\
\hline C57B1/10 & b & $\mathrm{b}$ & b & $\mathrm{b}$ & b & $b$ & $31 \pm 5$ & 0 & 0 \\
\hline C57B1/6 & $\mathbf{b}$ & b & b & $b$ & b & b & $32 \pm 4$ & -2 & -4 \\
\hline B10.M & $\mathbf{f}$ & f & $\mathrm{f}$ & $\mathrm{f}$ & f & $\mathrm{f}$ & $28 \pm 6$ & 3 & 0 \\
\hline A.SW & $\mathbf{s}$ & $\mathbf{s}$ & $\mathbf{s}$ & $\mathbf{s}$ & s & $\mathbf{s}$ & $27 \pm 4$ & 3 & 0 \\
\hline A.TH & $\mathbf{s}$ & $\mathbf{s}$ & s & s & s & $\mathbf{s}$ & $20 \$$ & 0 & 4 \\
\hline
\end{tabular}

* Spleen cells were used throughout.

$\dagger \%$ inhibition $=100 \times 1-\{[(\%$ rosettes after test serum $) /(\%$ rosettes after A.SW serum $)]\}$. Both sera were used at $1 / 100$ dilution (plateau values).

$\ddagger$ Male and female mice were tested : results represent mean values from at least 3 different experiments. $\$$ Only one experiment was done.

\| Normal CRC numbers are the percentage of rosettes after preincubation with normal A.SW serum (which did not affect the normal numbers in each case).

TABLE 4. Absorption of $\mathrm{C}^{\prime}$ receptor inhibiting activity tested in AKR spleen cells

\begin{tabular}{|c|c|c|c|}
\hline Serum & $\begin{array}{l}\text { Strain used for } \\
\text { absorption * }\end{array}$ & $\begin{array}{l}\% \mathbf{C}^{\prime} \text { rosette inhibition } \\
\text { after absorption } \dagger\end{array}$ & $\begin{array}{c}\% \mathrm{C}^{\prime} \text { rosette inhibition } \\
\text { before absorption }\end{array}$ \\
\hline BALB/c anti-CBA $(1 / 100)$ & $\begin{array}{ll}\text { CBA/H } & (-) \\
\text { AKR } & (+) \\
\text { BALB/c } & (-) \\
\text { A.TH } & (-)\end{array}$ & $\begin{array}{l}25 \\
20 \\
72 \\
73\end{array}$ & 70 \\
\hline A.TH anti-A.TL $(1 / 100)$ & $\begin{array}{l}\text { CBA/H }(-) \\
\text { AKR }(+) \\
\text { BALB/c } \stackrel{(-)}{(-)} \\
\text { A.TH }(-)\end{array}$ & $\begin{array}{l}26 \\
21 \\
69 \\
73\end{array}$ & 73 \\
\hline
\end{tabular}

* In brackets $=\left\{\begin{array}{l}+, \text { strain susceptible to inhibition } \\ -, \text { strain non susceptible to inhibition }\end{array}\right\}$.

$\uparrow$ Absorptions were accomplished by using $1: 5(\mathrm{v}: \mathrm{v})$ packed spleen cells: $1 / 5$ dilution of serum. After incubating $30 \mathrm{~min}$ at $37^{\circ} \mathrm{C}$, the mixture was placed rotating at $4^{\circ} \mathrm{C}$ for a further $6 \mathrm{hr}$.

$\mp$ See footnote table 3 . 
TABLE 5.

\begin{tabular}{|c|c|c|c|c|c|c|c|}
\hline & \multirow[b]{3}{*}{ Preincubation with } & \multicolumn{6}{|c|}{ Strains and $\mathrm{H}-2$ complex (K I-A I-B I-C S D) } \\
\hline & & \multicolumn{2}{|c|}{$\begin{array}{c}\text { AKR } \\
\text { (kkkkkk) }\end{array}$} & \multicolumn{2}{|c|}{$\begin{array}{l}\mathrm{B} 10 . \mathrm{A}(2 \mathrm{R}) \\
(\mathrm{kkkdd} / \mathrm{b})\end{array}$} & \multicolumn{2}{|c|}{$\begin{array}{l}\text { B10.A(5R) } \\
\text { (bbb/ddd) }\end{array}$} \\
\hline & & $\% \mathrm{CRC}+$ & $\begin{array}{c}\% \\
\text { inhibition }\end{array}$ & $\% \mathrm{CRC}$ & $\begin{array}{c}\% \\
\text { inhibition }\end{array}$ & $\% \mathrm{CRC}$ & $\begin{array}{c}\% \\
\text { inhibition }\end{array}$ \\
\hline \multirow{13}{*}{ 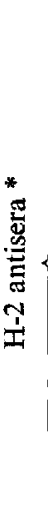 } & Normal A.SW serum & & & & & & \\
\hline & (control) & $36 \pm 3$ & - & $29 \pm 4$ & - & $30 \pm 6$ & - \\
\hline & 1 1-vs kkkkkk & $9 \pm 1$ & 75 & $8 \pm 3$ & 72 & $7 \pm 3$ & 76 \\
\hline & 2-vs skkkkd & $10 \pm 3$ & 72 & $9 \pm 1$ & 69 & $9 \pm 2$ & 70 \\
\hline & 3 - vs k kkkddb & $8 \pm 2$ & 77 & $5 \pm 2$ & 82 & $8 \pm 1 \cdot 5$ & 73 \\
\hline & 4 -vs bbbddd & $10 \pm 2$ & 72 & $6 \pm 2$ & 79 & $10 \pm 3$ & 66 \\
\hline & 5-vs bbbddd & $5 \pm 3$ & 86 & $6 \pm 3$ & 79 & $7 \pm 2$ & 76 \\
\hline & 6-vs dddddk & $8 \pm 3$ & 77 & $7 \pm 2$ & 75 & $8 \pm 1$ & 73 \\
\hline & 7-vs kkkddd & $11 \pm 3$ & 69 & $8 \pm 2$ & 72 & $8 \pm 1$ & 73 \\
\hline & 8 -vs skkk $\overline{k d d}$ & $30 \pm 6$ & 16 & $27 \pm 4$ & 6 & $25 \pm 4$ & 16 \\
\hline & 9 -vs dddddd $\ddagger$ & 31 & 13 & N.T. & N.T. & 30 & 0 \\
\hline & Rabbit anti-mouse Ig & $34 \pm 5$ & 5 & $30 \pm 2$ & -3 & $28 \pm 5$ & 6 \\
\hline & Rabbit anti-mouse $\mathrm{BA} \theta$ & $31 \pm 3$ & 13 & $30 \pm 4$ & -3 & $29 \pm 2$ & 3 \\
\hline
\end{tabular}

* For sera details consult table 1.

$\dagger$ Values calculated from 3 separate experiments $\%$ inhibition $=100 \times 1-[(\% \mathrm{CRC}$ (mean) test $) /(\% \mathrm{CRC}$ (mean) control)] $1,2: 1 / 100$ dilution; Rest :1/20 dilution.

$¥$ Numbers shown are mean of two separate experiments.

$\mathrm{BA} \theta=$ brain associated theta.

various $\mathrm{H}-2$ regions, concentrating mainly on those antisera raised in congenic strains. Table 5 shows the results of these experiments. The significant facts about the antisera were: (i) mere binding of antibody to the cell surface was not sufficient to inhibit CR binding. Although rabbit anti-mouse $\mathrm{Ig}$ and rabbit anti mouse brain-associated $\theta$ (BA $\theta$ ) bind to subpopulations of CR lymphoid cells (Arnaiz-Villena et al., 1974) no EAC rosette inhibition is seen with these antisera; (ii) an $\mathrm{H}-2$ difference was sufficient to produce a positive serum; (iii) $\mathrm{H}-2$ difference in the $\mathrm{K}$, I-A or I-B region did not produce positive antisera (serum 8 and 9); I-C, S or D region differences were required to produce positive sera, and all positive sera could be explained on the basis of a locus between the $S$ and $D$ regions, assuming that the crossing over between $\mathrm{S}$ and $\mathrm{D}$ occurs in different places in different recombinant strains. Other possibilities will be discussed later.

To summarize, the findings point to the characteristic CRIS being under complex genetic control, with at least part of the control being in the D end of the H-2 complex. The inhibitory activity in antisera behaves like an antibody directed against antigens controlled by the $\mathrm{D}$ end of the $\mathrm{H}-2$ complex.

\section{DISCUSSION}

We have established that a variety of anti-H-2 sera contain an activity capable of specifically inhibiting the EAC rosettes of certain mouse strains. The activity resembles an antibody in being present only in immune sera, being specific and absorbable, and being found in both 
the IgG and $F\left(a b^{\prime}\right)_{2}$ fractions of the antisera. The activity seems to be raised against gene products controlled by the I-C, S or D regions of the $\mathrm{H}-2$ complex, and the ability to be inhibited by the antisera seems to map in the I-C or S region, but is influenced by factors other than the mere presence of the gene product on the cell surface. From previous sțudies we know that only a subpopulation of $C R$ bearing cells is inhibited in this way, perhaps because only this subpopulation expresses the gene product required to bind the antibody. Evidence indicates that this subpopulation is the lymphoid, rather than myeloid, subpopulation of CR bearing cells. Therefore, EDTA sensitivity $\left[\mathrm{Mg}^{2+}\right.$ dependence (Lay \& Nussenzweig, 1968)] together with resistance to inhibition by H-2 antisera would be two characteristics of mouse myeloid CRs differentiating them from lymphoid CRs.

The $\mathrm{S}$ region of the $\mathrm{H}-2$ complex is a natural focus for attention for studies of complement receptor genetics. It has remained silent in terms of serologically detectable cell surface antigens, but it has been demonstrated that the $S$ region controls serum complement levels in mouse (Démant et al., 1973). Since it would be natural to expect that some cell surface antigens will be controlled by the $S$ region (like the $K, I, D$, and TL regions) it would not be surprising if the $S$ region controlled at least some aspects of the genetic control of CRs. However, the extreme complexity of complement systems, with their enzyme cascades and multiple inhibitors, leads us to suspect that complement receptors will depend on and be affected by serum proteins, cofactors and inhibitors in a similarly complicated fashion. Certainly the existence of several kinds of complement receptor has been reported in humans: for C3 and C3b (Theofilopoulos et al., 1974), for C4 (Bokisch \& Sobel, 1974) and for C3d (Ross et al., 1973) and in mouse (Okada \& Okada, 1974).

One of the most puzzling findings in these experiments is that with the initial two antisera used to define CRIS, (A.TH $\alpha$ A.TL and BALB/c $\alpha \mathrm{CBA} / \mathrm{H}$ ), BALB/c is negative but DBA/2 is positive, and $\mathrm{CBA} / \mathrm{H}$ is negative while $\mathrm{AKR}$ is positive. The possible explanations of these findings are worthy of consideration: (i) the antigen recognized by the inhibiting antibody is non H-2 linked; but how can this account for antibody production in congenic mice differing only in small segments of the $\mathrm{H}-2$ complex ? Also, this would not agree with the $\mathrm{H}-2$ linkage shown for CRIS; (ii) $\mathrm{H}-2$ haplotypes, such as $\mathrm{H}-2^{\mathrm{d}}$ may differ at previously unknown S or D region loci from one another, i.e. the H-2 complex of BALB/c and the H-2 complex of DBA/2 may be genotypically different. This explanation is unconventional but has been invoked previously to explain genetic findings in this region (Gelfand et al., 1974); (iii) H-2 genes of genotypically H-2 identical mice (e.g. BALB/c and DBA/2) may produce gene products which are altered by non $\mathrm{H}-2$ factors (? inhibitors, cofactors) to be phenotypically different, such that an S region antigen expressed in DBA/2 may be absent in BALB/c; (one preliminary observation compatible with this hypothesis is that antiserum BALB/c anti DBA/2 inhibits DBA/2 and AKR CR but not BALB/c CR, Arnaiz-Villena \& Halloran, unpublished observations).

Can the H-2 genetic influence on CRIS be correlated with any known H-2 linked gene? (for review see Shreffler \& David, 1975). Certainly the T and Tla genes can be easily ruled out, as can the $\mathrm{H}-2 \mathrm{~K}$ and $\mathrm{H}-2 \mathrm{D}$ genes as detected in conventional serological studies, because antisera raised between animals differing only in the I and $S$ regions are positive. The Ia specificities currently known can be ruled out by the occurrence of positive sera raised across no $I$ region differences (Table 5, serum 6). The H-2G region (David et al.,1975; Klein et al., 1975) is incompletely understood but has no known gene products on cells other than erythrocytes, and the known alloantigen in this region could not explain these 
findings. The $\mathrm{S}$ region has two known makers, the $\mathrm{S}$ protein and the sex-limited Slp trait, neither of which correlate with our findings. One interesting marker, CRL-1 (Gelfand et al., 1974) in the $\mathrm{D}$ end of the $\mathrm{H}-2$ complex to the right of $\mathrm{S}$, has some interesting similarities with our CRIS H-2 linked component, but is distinguishable from it by its mapping and strain distribution (for example, B10.A(2R) is positive for CRIS but negative for CRL-1). At present we can find no $\mathrm{H}-2$ linked characteristic which correlates with the H-2 linked CRIS locus. An obvious caveat in the interpretation of our findings is the relative lack of information about mouse $\mathrm{C}^{\prime}$ and $\mathrm{CRs}$, the factors regulating them, and their interactions with one another. For example, could complement components and related enzymes, which are found and possibly produced in lymphoid tissues, alter the behaviour of the CR so that CRIS positive cells could become CRIS negative? If so, this would help to explain how mice which are apparently genotypically identical at the $\mathrm{H}-2$ locus could be phenotypically different for an H-2 linked characteristic. Furthermore, what is the role of the antibody in CR inhibition, and is there any role for complement components in the antiserum in the inhibition, since complement components have been shown to modify CR binding (Miller et al., 1973)? Any such interactions would have to take into account that the $F\left(a b^{\prime}\right)_{2}$ portions of the antibody are almost as inhibitory as the $\operatorname{IgG}$, and the high titre of the activity in some sera.

For now, a working hypothesis for the ability of anti-H-2 sera to inhibit CR would involve interaction of the antibody with the product of an H-2 linked gene (possibly located between Ss and H-2D) which would result in inhibition or non inhibition depending upon influence from other genes, possibly non $\mathrm{H}-2$ linked.

We are particularly interested in the implications of this work for $\mathrm{H}-2$ serology (and the serologic study of the major histocompatibility systems of other species). H-2 antisera contain new and previously unsuspected activities against $\mathrm{D}$ end antigens, undetected by conventional means. Furthermore, D end gene products seem to be intimately involved with the complement receptor, just as they are intimately involved in determining complement receptor cell levels in neonatal spleens (Gelfand et al., 1974) and in serum complement levels (Demant et al., 1973).

\section{ACKNOWLEDGMENTS}

We thank Volker Schirrmacher for $F\left(a b^{\prime}\right)_{2}$ and IgG preparations and Denise Brown for helping with the manuscript. This work was supported by the Spanish Department of Education and Science, the Medical Research Council of Canada and the N.I.H. Grant A1 11967.

\section{REFERENCES}

Arnaiz-Villena, A., Gyongyossy, M.I.C. \& Playfair, J.H.L. (1974) Rosette formation by mouse lymphocytes. II. T-cell specificities in a CRL sub-population. Clinical Experimental Immunology, 18, 177.

ARNAIZ-VILlENA, A. \& HAY, F.C. (1975) Complement receptor lymphocytes: analysis of immunoglobulin on their surface and further evidence of heterogeneity. Immunology, 28, 719.

Arnaiz-Villena, A., Halloran, P., David, C.S. \& Festenstein, H. (1975) Lymphoid complement receptors are inhibited by anti-H-2 antisera raised across D end incompatibilities. Folia Biologica. Praha. 21, 432.

Bainco, C., Patrick, R. \& Nussenzweig, V. (1970) A population of lymphocytes bearing a receptor for antigen-antibody-complement complexes. I. Separation and characterisation. Journal of Experimental Medicine, 133, 702 .

Bukisch, V.A. \& Sobel, A.T. (1974) Receptor for the fourth component of complement on human B lymphocytes and cultured lymphoblastoid cells. Journal of Experimental Medicine, 140, 1336. 
DAvid, C.S., Stimpfing, J.H. \& ShrefFleR, D.C. (1975) Identification of specificity H-2.7 as an erythrocyte antigen: Control by an independent lcous, $\mathrm{H}-2 \mathrm{G}$, between $\mathrm{S}$ and $\mathrm{D}$ regions. Immunogenetics, 2, 131.

Démant, P., Capkova, J., Hinzova, E. \& Voracova, B. (1973) The role of the histocompatibility 2-linked Ss-Slp region in the control of mouse complement. Proceedings of the National Academy of Sciences, Washington, 70, 863.

DICKLER, H.B. \& SACHS, D.H. (1974) Evidence for identity or close association of the Fc receptor of B-lymphocytes and alloantigens determined by the Ir region of the H-2 complex. Journal of Experimental Medicine, 140, 779.

Gelfand, M.C., SaChs, D., LiebermanN, R. \& Paul, W.E. (1974) III. H-2 linkage of a gene controlling the rate of appearance of complement receptor lymphocytes. Journal of Experimental Medicine, 139, 1142.

Halloran, P., Schirrmacher, V. \& Festenstein, H. (1974) A new sensitive assay for antibody against cell surface antigens based on inhibition of cell dependent antibody-mediated cytotoxicity. I. Specificity and sensitivity. Journal of Experimental Medicine, 140, 1348.

Halloran, P., SchirRmacher, V. \& David, C.S. (1975) The specificity and significance of the inhibition of Fc receptor binding by anti-H-2 sera. Immunogenetics, $2,349$.

Kiein, J., Bach, F.H., Festenstein, H., McDevitt, H.O., Shreffler, D.C., Sneli, G.D. \& Stimpfling, J.H. (1974) Genetic nomenclature for the H-2 complex of the mouse. Immunogenetics, 1, 184.

KLein, J., HAuPTfELd, V. \& HAUPTFeld, M. (1975) Evidence for a fifth (G) region in the H-2 complex of the mouse. Immunogenetics, $2,141$.

LAY, W.H. \& NUSSENZWEIG, V. (1968) Receptors for complement on leukocytes. Journal of Experimental Medicine, 138, 1044

Miller, G.W., SALUK, P.H. \& NussenzweIG, V. (1973) Complement-dependent release of immunocomplex from the lymphocyte surface. Journal of Experimental Medicine, 138, 495.

OKaDA, H. \& OKADA, N. (1974) Complement receptor on cell membrane. II. Separation from mouse plasma of two essential factors for complement receptors on cell membranes. Japan Journal of Experimental Medicine, 44, 301.

PARISH, C.R. \& HAYward, J.D. (1974) The lymphocyte surface. I. Relation between Fc receptors, C3 receptors and surface immunoglobulin. Proceedings of the Royal Society $B, 187,47$.

Ross, G.D., Polley, M.J., Rabellino, E.M. \& GREY, H.M. (1973) Two different complement receptors on human lymphoyctes. One specific for $\mathrm{C} 3 \mathrm{~b}$ and one specific for C3b-inactivator cleaved C3b. Journal of Experimental Medicine, 138, 798.

SchirRmacher, V., Halloran, P. \& David, C.S. (1975) Interactions of Fc receptors with antibodies against Ia antigens on other cell surface components. Journal of Experimental Medicine, 141, 1201.

SHREFFLER, D. \& DAVID, C.S. (1975) The H-2 major histocompatibility complex and the I immune response region: genetic variation, function and organisation. Advances in Immunology, 20, 125.

SNELL, G. (1968) Catalogue of mouse alloantisera. Transplantation Immunology Branch Publication, National Institute of Allergy and Infectious Disease, National Institutes of Health, Bethesda, Maryland.

Theofilopoulos, A.N., Bokisch, V.A. \& Dixon, F.J. (1974) Receptors for soluble C3 and C3b on human lymphoblastoid (Raji) cells. Properties and biological significance. Journal of Experimental Medicine. $139,196$. 